\title{
Therapy-Induced Growth and Sexual Maturation in a Developmentally Infantile Adult Patient with a PROP1 Mutation
}

\author{
Ludmila Brunerova ${ }^{1 *}$, Ivana Cermakova ${ }^{2}$, Bozena Kalvachova ${ }^{2}$, Jana Skrenkova ${ }^{3}$, \\ Renata Poncova ${ }^{3}$ and Petr Sedlak ${ }^{4}$ \\ 'Faculty Hospital Královské Vinohrady, 3rd Faculty of Medicine, II. Department of Internal Medicine, Prague, Czechia, \\ ${ }^{2}$ Institute of Endocrinology, Prague, Czechia, ${ }^{3} 1$ st Faculty of Medicine, Department of Obstetrics and Gynecology, \\ General Teaching Hospital, Prague, Czechia, ${ }^{4}$ Faculty of Science, Department of Anthropology and Human Genetics, \\ Charles University, Prague, Czechia
}

\section{OPEN ACCESS}

Edited by:

Margaret Cristina Da

Silva Boguszewski,

Federal University of

Paraná, Brazil

Reviewed by:

Yona Greenman,

Tel Aviv Sourasky Medical

Center, Israel

Mirtha Adriana Guitelman,

Independent Researcher,

Durand Hospital, Argentina

*Correspondence:

Ludmila Brunerova

brunerova@seznam.cz

Specialty section: This article was submitted to

Pituitary Endocrinology,

a section of the journal

Frontiers in Endocrinology

Received: 21 June 2017 Accepted: 23 October 2017 Published: 13 November 2017

Citation:

Brunerova L, Cermakova I, Kalvachova B, Skrenkova J, Poncova R and Sedlak P (2017)

Therapy-Induced Growth and

Sexual Maturation in a

Developmentally Infantile Adult Patient with a

PROP1 Mutation.

Front. Endocrinol. 8:309. doi: 10.3389/fendo.2017.00309
Background: Hypopituitarism as a result of PROP1 (prophet of PIT1) mutation represents the most common genetic cause of combined deficiency of pituitary hormones and due to growth retardation it is typically diagnosed in childhood.

Case description: We present a unique case report of a prepubertal woman with growth retardation in whom combined pituitary hormone deficiency [central hypopituitarism, hypogonadism, and growth hormone $(\mathrm{GH})$ deficiency] caused by homozygous mutation c.150delA in the PROP1 gene was diagnosed late in young adulthood due to unfavorable life circumstances. Through cautiously combined GH therapy and sex hormone therapy, she has achieved better than expected height (exceeding predictions based on family height) and sexual maturation, including regular menstrual cycles.

Conclusion: Early diagnosis of panhypopituitarism due to PROP1 mutation is essential for successful treatment; however, our case report shows that carefully titrated GH treatment and sex hormone substitution, although initiated in adulthood, enable restoration of physiological growth and sexual development in a hormonally infantile adult woman with a PROP1 mutation.

Keywords: growth, sexual maturation, PROP1 mutation, hormonal substitution therapy, growth hormone therapy

\section{INTRODUCTION}

Combined pituitary hormone deficiency (CPHD) is defined as missing production of two or more pituitary hormones and is sporadic in majority of cases; however, familial forms (with different manners of inheritance) have been also described (1). Although several genes which are involved in pituitary cell differentiation (e.g., PIT-1, PROP1, LHX-3, LHX-4, HESX-1, SIX-6, OTX-2, PTX-2, GLI-2, and SOX-3) were identified as genetic causes of CPHD, their overall frequency among the cases is low, with mutation of PROP1 being the most common one $(2,3)$.

PROP1 is the abbreviation from English "prophet" (precursor) of the PIT1 transcription factor responsible for development of the anterior part of the pituitary lobe during embryogenesis. PIT1 is a homeobox protein encoded by the PROP1 gene, essential for the proper maturation of 
specialized cell types in the anterior part of the pituitary gland which produce and secrete polypeptide hormones in response to stimulation signals from the hypothalamus and stimulatory feedback from target organs (4).

Mutation of PROP1 leads to CPHD of all pituitary hormones: growth hormone $(\mathrm{GH})$, thyroid-stimulating hormone (TSH), luteinizing hormone ( $\mathrm{LH})$, follicle-stimulating hormone (FSH), prolactin (PRL), and adrenocorticotropic hormone (ACTH) (1) and represents probably the most common genetic cause affecting $18-24 \%$ of tested patients with CPHD; in familial forms inherited in an autosomal recessive manner (1-3).

Clinical and hormonal phenotype is highly variable, but typically, PROP1 gene mutation is manifested as hypopituitarism with growth failure as the first sign and thus it is detected in early childhood. Central hypothyroidism usually appears later in childhood and varies in its severity. Delayed or absent sexual maturation is observed in the second decade of life. ACTH insufficiency is less common and, if it occurs, it is more likely in adulthood (5-7). In general, no correlation has been observed between different PROP1 pathogenic variants and the phenotype (6-8).

Diagnosis of CPHD is based on the detection of hormonal deficiencies using standard basal hormonal examinations and challenge tests. Mutation of PROP1 can then be confirmed by molecular-genetic testing $(6,9)$ using sequence analysis, which detects different gene variants classified with respect to their phenotypic impact as benign, likely benign, of uncertain significance, likely pathogenic or pathogenic, or by other methods [e.g., quantitative polymerase chain reaction (PCR) or chromosomal microarray].

Magnetic resonance imaging (MRI) is the technique of choice in the diagnosis of patients with CPHD. Although the correlation of genetic mutations with endocrine and MRI phenotypes has improved the management of some patients with CPHD (10), pituitary morphology, particularly in PROP1 mutation, is not very specific and varies widely from a small to an enlarged gland (11).

There is no causal treatment for PROP1 mutation cases; the therapy is focused on substitution of all the lacking hormones while respecting developmental aspects $(6,8,12)$.

We present a case of an adult woman with delayed diagnosis of CPHD secondary to PROP1 mutation, who due to certain life circumstances was still prepubertal but responded well to hormonal treatment. To the best of our knowledge, our case is exceptional in terms of growth as a result of GH treatment initiated in adulthood.

\section{CASE PRESENTATION}

The patient signed an informed consent statement and agreed on the examination as well as the presentation of her case, including the picture.

The patient was a young woman born in Ukraine in 1985. She was her mother's second uncomplicated pregnancy, with a term physiological delivery $(3,900 \mathrm{~g}, 53 \mathrm{~cm})$. Her parents and two sisters were healthy and of normal height (mother $158 \mathrm{~cm}$, father $165 \mathrm{~cm}$, and sisters both $170 \mathrm{~cm}$ ). Unfortunately, no medical records from Ukraine are available; the only source of information about her health status is the self-report by our patient. She stated having been treated with GH from 15 to 17 years due to growth retardation and gained $25 \mathrm{~cm}$ of height. At the same time, she was treated with iodine (Jodomarin) $100 \mu \mathrm{g}$ daily. No other hormonal treatment was indicated in Ukraine at that time. She moved to Czechia at the age of 25 years.

She was referred by her GP to an endocrinologist for suspected hypopituitarism (small stature and primary amenorrhea) in May 2013. Surprisingly, the patient herself did not express any concerns either about her childish appearance or the absence of menstrual periods, or about the lack of secondary sexual signs including pubic and axillary hair and breasts. She denied perceiving any potential symptoms connected with hypothyroidism or hypocortisolism. However, during examination she displayed an infantile appearance $(149 \mathrm{~cm}, 43 \mathrm{~kg})$, pale skin, puffy face, no axillary or pubic hair (Tanner AH1 and PH1, respectively), no breast development (Tanner B1-2), and with no history of a menstrual cycle (Figure 1).

\section{Laboratory Assessment Methods}

The laboratory assessment was performed in the Laboratory of the Institute of Endocrinology using the following methods presented in the form: hormone, method, producer, and reference range--in relevant hormones corrected for age and gender

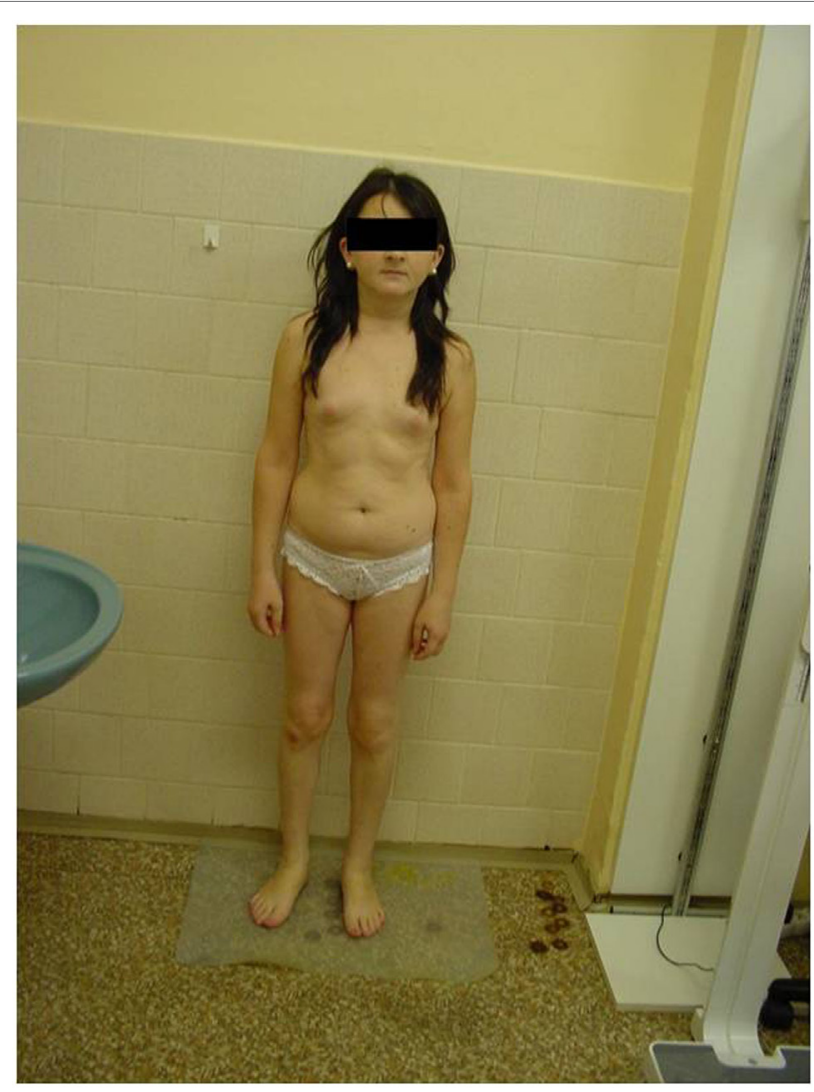

FIGURE 1 | Picture of our patient at the age of 27 years. 
and menstrual cycle phase: fT3 [electroluminescence (ECLIA), Roche, 3.1-6.8 pmol/L]; fT4 (ECLIA, Roche, 12-22 pmol/L); TSH (ECLIA, Roche, 0.27-4.2 mIU/L); estradiol (ECLIA, Roche, reference range: $0.0454-0.854 \mathrm{nmol} / \mathrm{L}$ follicular phase); FSH (ECLIA, Roche, 3.5-12.5 IU/L follicular phase); LH (ECLIA, Roche, 2.4-12.6 IU/L follicular phase); S-cortisol (RIA, Immunotech, 263$724 \mathrm{nmol} / \mathrm{L}$ ); ACTH (ECLIA, Roche, 7.2-63.3 ng/L); androstendione [radioimmunoassay (RIA), Immunotech, 2.47-9.4 nmol/L]; DHEA (RIA, Immunotech, 7.3-57 nmol/L); DHEAS (RIA, Immunotech, 2.4-14.5 $\mu \mathrm{mol} / \mathrm{L}$ ); insulin-like growth factor (IGF-I) [immune-radiometric analysis (IRMA), Immunotech, 150$450 \mathrm{ng} / \mathrm{mL}$ ]; GH (ECLIA, Roche, 0.05-10 $\mu \mathrm{g} / \mathrm{L}$ ); and PRL (ECLIA, Roche, 4.79-23.3 $\mu \mathrm{g} / \mathrm{L})$.

\section{Results}

Basal hormonal assessment and the results of challenge tests are presented in Table 1. In general, we confirmed central hypothyroidism and hypogonadism, decreased adrenocortical reserve (with basically normal S-cortisol, however insufficient stimulation in insulin test), normal-to-low adrenal androgens, low-normal PRL, and undetectably low IGF-I with no stimulation of $\mathrm{GH}$ in either of the stimulation tests: arginin and insulin challenge tests. In Czechia, two confirmation tests are necessary for health insurance approval of $\mathrm{GH}$ treatment in adulthood.

\section{Other Examinations}

The karyotype was normal female (46, XX). Gynecologic examination revealed small ovaries and an infantile uterus. Densitometry showed significantly decreased bone mineral

TABLE 1 | Basic laboratory assessment and results of functional tests.

\begin{tabular}{|c|c|c|}
\hline $\begin{array}{l}\text { Hormonal axis/ } \\
\text { hormone }\end{array}$ & $\begin{array}{l}\text { Basic laboratory } \\
\text { assessment }\end{array}$ & Challenge tests \\
\hline Thyroid & $\begin{array}{l}\text { fT4 } 3.1 \mathrm{pmol} / \mathrm{L} ; \text { fT3 } \\
2.2 \mathrm{pmol} / \mathrm{L}, \mathrm{TSH} 1.3 \mathrm{mlU} / \mathrm{L}\end{array}$ & $\begin{array}{l}\text { TSH in TRH test: } \\
1.3-1.7-2.44 \mathrm{mU} / \mathrm{L}\end{array}$ \\
\hline Gonadal & $\begin{array}{l}\mathrm{LH}<0.2 \mathrm{U} / \mathrm{L} ; \mathrm{FSH} 0.7 \mathrm{U} / \mathrm{L} \text {, } \\
\text { estradiol }<0.03 \mathrm{nmol} / \mathrm{L}\end{array}$ & $\begin{array}{l}\text { LHRH test: FSH } \\
0.2-1.3-0.3 \mathrm{IU} / \mathrm{L} ; \mathrm{LH} \\
\text { low-0.2-0.1 IU/L, estradiol } \\
0.4 \mathrm{nmol} / \mathrm{L}\end{array}$ \\
\hline Adrenocortical & $\begin{array}{l}\text { S-cortisol } 323 \text { nmol/L, } \\
0.175 \mathrm{nmol} / \mathrm{L}, \text { ACTH } 27.7 \mathrm{ng} / \mathrm{L}\end{array}$ & $\begin{array}{l}\text { S-cortisol in insulin test: } \\
\text { 453-294-394-273 nmol/L }\end{array}$ \\
\hline Adrenal androgens & $\begin{array}{l}\text { DHEAS } 0.53 \mu \mathrm{mol} / \mathrm{L}, \text { DHEA } \\
5.1 \mathrm{nmol} / \mathrm{L} \text {, androstenedione } \\
2.4 \mathrm{nmol} / \mathrm{L}\end{array}$ & \\
\hline $\mathrm{GH}$ & IGF-1 undetectably low & $\begin{array}{l}\text { GH in arginine test: } \\
0.05-0.03-0.04-0.05- \\
0.04 \mu \mathrm{g} / \mathrm{L} \\
\text { GH in insulin test: } 0.08- \\
0.07-0.05-0.03- \\
0.03 \mu \mathrm{g} / \mathrm{L}\end{array}$ \\
\hline
\end{tabular}

Prolactin

$6.4 \mu \mathrm{g} / \mathrm{L}$

ACTH, adrenocorticotropin; DHEA, dehydroepiandrosterone; DHEA-S, dehydroepiandrosterone-sulfate; FSH, follicle-stimulating hormone; $\mathrm{fT}$, free triiodothyronine; $\mathrm{TT} 4$, free thyroxin; GH, growth hormone; IGF-1, insulin-like growth factor 1; LH, luteinizing hormone; $L H R H, L H$-releasing hormone; $T R H$, thyroliberin; $\mathrm{TSH}$, thyroid stimulating hormone. density (BMD) in relation to age ( $Z$-score in L-spine -4.5 and in proximal femur -2.1). Molecular biologic examination using sequence analysis confirmed homozygous mutation c.150delA in the PROP1 gene (position of the gene 5q35.3). Unfortunately, complete molecular-genetic analysis including the relatives of our patient was not possible to perform since the whole family lives in a small village in Ukraine. MRI revealed a smaller but otherwise normal pituitary gland (Figure 2).

\section{Therapy for Central Hypothyroidism and Hypocortisolism}

Therapy with levothyroxine was started in May 2013 and continuously titrated up to a final dose of $125 \mu \mathrm{g}$ daily (reached in September 2016) in order to achieve euthyroid status (fT4 14; fT3 $4.2 \mathrm{pmol} / \mathrm{L}$ ). After confirmation of a decreased adrenocortical reserve and due to decreasing basal S-cortisol to the lower limit of the normal range in repetitive measurements, hydrocortisone $15 \mathrm{mg}$ (10-5-0 mg) was administered daily in September 2013. Calcium $600 \mathrm{mg}$ and vitamin D $400 \mathrm{U}$ daily were started at the same time.

\section{Auxology and GH Therapy}

The titration of $\mathrm{GH}$ and growth progression are presented in Table 2. Bone age at the first auxologic examination, when the patient was 26.7 years of age, assessed using the TW3-CARP method (13), was 10.2 years and revealed an extreme delay ( -16.5 years!) compared to the patient's chronologic age. $\mathrm{GH}$ therapy was initiated in November 2013 with Humatrope 12, with an initial infantile dose of $1.35 \mathrm{mg} /$ day $(0.031 \mathrm{mg} / \mathrm{kg} /$ day). During the first months, the dose had to be decreased to $0.3 \mathrm{mg} /$ day $(0.007 \mathrm{mg} / \mathrm{kg} /$ day) in response to side effects (eyelid edema and ankle pain). After 11 months, the dose was increased

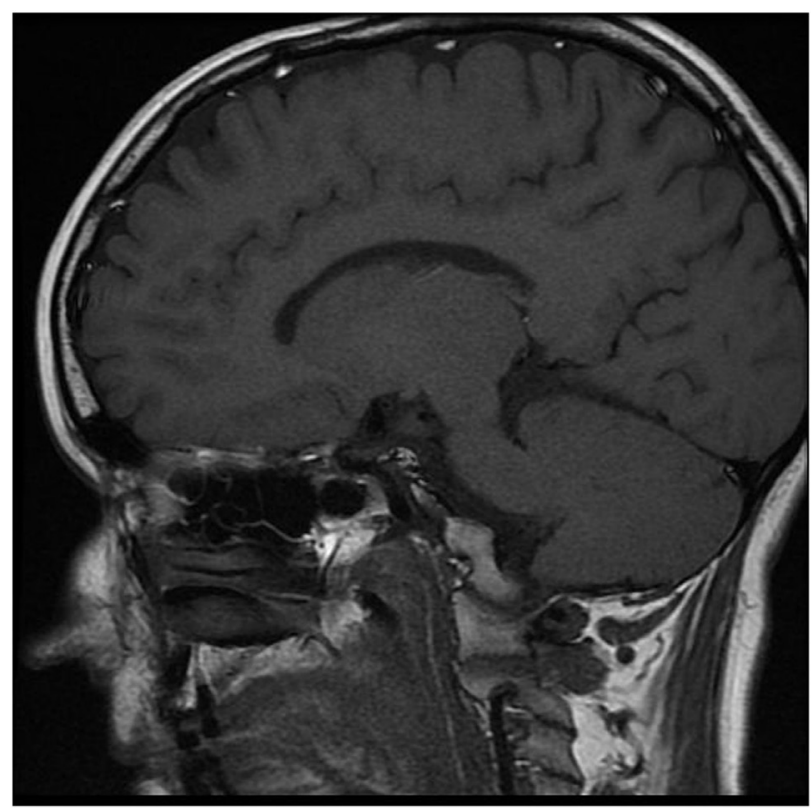

FIGURE 2 | Magnetic resonance imaging of smaller pituitary gland. 
TABLE 2 | Titration of GH therapy and sex hormone substitution therapy with clinical correlates.

\begin{tabular}{|c|c|c|c|c|c|c|c|c|}
\hline Date & $\begin{array}{c}\text { Age } \\
\text { (years) }\end{array}$ & $\begin{array}{l}\text { Height } \\
\text { (cm/SDS) }\end{array}$ & $\begin{array}{c}\text { GV } \\
\text { (cm/year) }\end{array}$ & $\begin{array}{l}\text { GH dose } \\
\text { (mg/day) }\end{array}$ & $\begin{array}{l}\text { IGF-1 } \\
\text { (ng/ml) }\end{array}$ & $\begin{array}{l}\text { Dose of HST } \\
\text { (mg/day) }\end{array}$ & GUS (mm) & Hormonal cytology (\%) \\
\hline $11 / 13$ & 27.2 & $149 /-2.9$ & & 1.35 & & & $\cup 15 \times 10$ & $\begin{array}{l}\text { MI 98-2-0 } \\
\text { El O }\end{array}$ \\
\hline $12 / 13$ & 27.3 & $149 /-2.9$ & & 0.6 & 10.0 & & & \\
\hline $2 / 14$ & 28.3 & $151.8 /-2.46$ & 2.8 & 0.3 & 42.0 & E 0.1 & $U 18 \times 10$ & $\begin{array}{l}\text { MI 98-2-0 } \\
\text { El } 0\end{array}$ \\
\hline $5 / 14$ & 28.5 & $154.6 /-2.01$ & & & 117.0 & E 0.2 & $\begin{array}{c}\text { U } 29 \times 10 \times 24 \\
\text { O homog }\end{array}$ & $\begin{array}{l}\text { MI 90-10-0 } \\
\text { El 0 }\end{array}$ \\
\hline $7 / 14$ & 28.7 & $158.0 /-1.47$ & & & & E 0.3 & $\begin{array}{c}\text { U } 40 \times 9 \times 16 \\
\text { O physiol. }\end{array}$ & $\begin{array}{l}\text { MI 80-20-0 } \\
\text { El } 0\end{array}$ \\
\hline $2-3 / 15$ & 29.3 & $160.3 /-1.11$ & 8.5 & 0.4 & & E 0.5 & & \\
\hline $5 / 15$ & 29.5 & $160.7 /-1.04$ & & & 11.0 & E 1 & $\begin{array}{c}\text { U } 40 \times 9 \times 16 \\
\text { Endom } 2 \\
\text { O physiol. }\end{array}$ & $\begin{array}{c}\text { MI 20-80-0 } \\
\text { El } 0\end{array}$ \\
\hline $9 / 15$ & 29.8 & $162.7 /-1.04$ & 0.8 & 0.4 & & E 2 & $\begin{array}{c}\cup 43 \times 19 \times 28 \\
\text { Endom } 3.7\end{array}$ & $\begin{array}{l}\text { Ml 0-99-1 } \\
\text { El 40 }\end{array}$ \\
\hline $11 / 15$ & 30.0 & & & & 111.0 & $E 2+D 20$ & $\begin{array}{c}\text { U } 56 \times 15 \times 34 \\
\text { Endom } 5\end{array}$ & $\begin{array}{l}\text { MI 0-90-10 } \\
\text { El } 5\end{array}$ \\
\hline $12 / 15$ & 30.3 & & & & & Induction of menarche & & \\
\hline $3 / 16$ & 30.3 & $162.9 /-0.69$ & 4.5 & 0.4 & 20.0 & Femoston 2/10 & & \\
\hline $9 / 16$ & 30.8 & $163.0 /-0.68$ & 0.4 & 0.4 & 93.0 & Femoston 2/10 & & \\
\hline $11 / 16$ & 31.0 & $163.5 /-0.61$ & 1.5 & 0.4 & & Femoston 2/10 & & \\
\hline
\end{tabular}

D, dydrogesterone; E, estradiol; El, eosinophilic index; Endom, endometrium thickness; Femoston 2/10, estradiol 2 mg, followed by estradiol 2 mg + dydrogesterone 10 mg; GH, growth hormone; GUS, gynecologic ultrasonography; GV, growth velocity; IGF-1, insulin-like growth factor 1; HST, hormonal substitution therapy; MI, maturation index; O, ovaries; $U$, uterus.

to $0.4 \mathrm{mg} /$ day $(0.009 \mathrm{mg} / \mathrm{kg} /$ day $)$, which was well tolerated. Auxologic examinations including X-rays were performed altogether five times during the treatment with constantly high difference between bone and chronologic ages. The last examination was performed in 2015 at the age of 29.7 years. The difference between bone (TW3-CARP $=12.8$ years) and chronologic ages was still high (16.9 years), growth physes were partially open and reached the morphologically perimenarcheal stage, and growth velocity correspondingly decreased to $0.8 \mathrm{~cm} /$ year. After induction of menarche, growth velocity increased to $4.5 \mathrm{~cm} /$ year and the remaining growth potential contributed to subsequent growth during the next year with a growth velocity of $1.5 \mathrm{~cm} /$ year.

Although the patient's compliance was not always optimal with suspected multiple missed injections, the patient achieved a final height of $163.5 \mathrm{~cm}$, which exceeded the lower limit of her familial range $158-175 \mathrm{~cm}$ (target height by Tanner) (14).

\section{Sexual Development and Sex Hormone Substitution Treatment (HST)}

The patient was examined by a pediatric gynecologist in February 2013 with the following findings: infantile vulva with posterior synechia and per rectum uterus infantilis. The second examination was performed 1 year later (patient related delay) and "miniestrogenization" with oral estradiol ( $0.1 \mathrm{mg}$ once daily orally) was started in February 2014. The titration of sex hormone treatment was guided by hormonal cytology - a feasible noninvasive and cheap method routinely used in pediatric gynecology for guidance of hormonal therapy. Normal smear shows the following types of squamous epithelial cells: superficial eosinophillic cells influenced by estrogens, intermediate cyanophillic cells influenced by progesteron, and immature basal and parabasal cells. Eosinophillic index (EI) - the percentage of eosinophillic superficial and cyanophillic parabasal cells-and maturation index (MI) - the percentage study of parabasal, intermediate, and superficial cells/100 cells counted from exfoliated epithelial cells of vaginal smear-describe the maturation of vaginal epithelium. The effect of estrogen is described as $\mathrm{MI}=0 / 10 / 90$, whereas the effect of progesterone is described as $\mathrm{MI}=0 / 90 / 10(15,16)$.

The titration of hormonal substitution therapy and findings from hormonal cytology and sonography of the uterus are presented in Table 2 and Figure 3. In general, therapy was well tolerated and a very prompt reaction of estrogendependent organs was observed. After 15 months (May 2015), secondary sexual signs developed to $\mathrm{B} 2, \mathrm{PH} 2, \mathrm{~A} 1$, and after 19 months of the treatment (in September 2015) to B4, PH2, A1. In November 2015, the uterus was well developed with a proper endometrium layer. At this point, progesterone (dydrogesterone) $10 \mathrm{mg}$ twice daily for 10 days was added to $2 \mathrm{mg}$ of estradiol; after its withdrawal, menarche was induced on December 11, 2015 and since that time, commercial Femoston 2/10 (estradiol $2 \mathrm{mg}$ daily 5 th-25th day of menstrual cycle and dydrogesterone $20 \mathrm{mg}$ 16th-25th day of menstrual cycle) has been administered. 


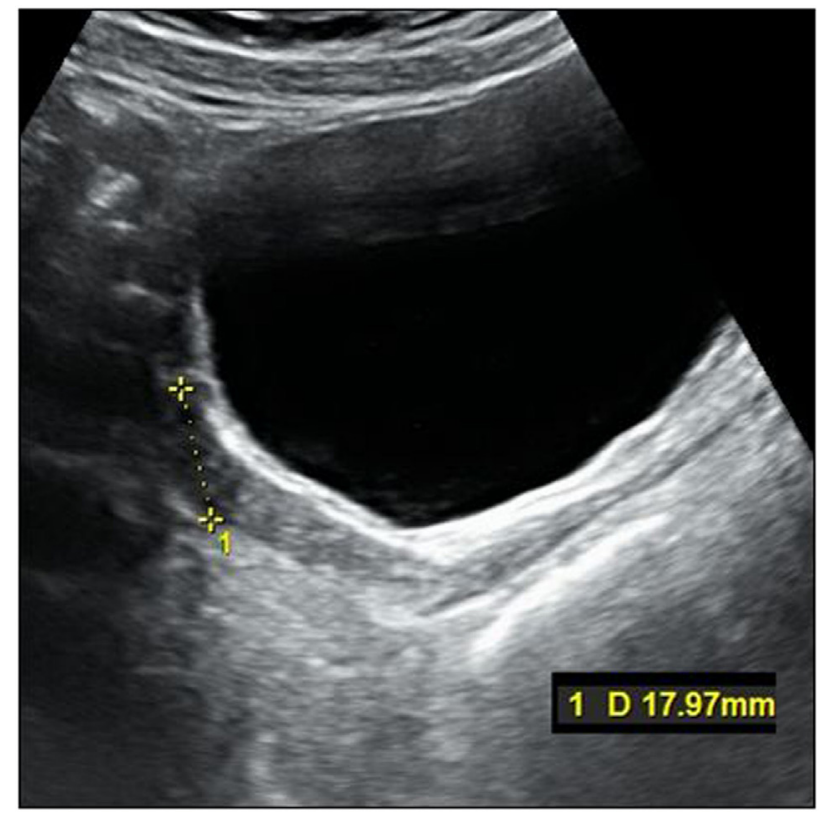

FIGURE 3 | Ultrasonography of uterus at the initiation of the treatment.

Currently, the patient continues with the established substitution of all above-mentioned pituitary hormones with levothyroxin, hydrocortisone, GH, and sex hormone therapy. The patient reports feeling well and is satisfied with the treatment results.

\section{DISCUSSION}

To our knowledge, such a case of a PROP1 mutation patient with growth retardation and absence of puberty diagnosed very late - at adult age-is quite exceptional. So far, only one case of a hormonally infantile (male) adult patient treated with GH has been presented without therapeutic details (17). Furthermore, two female patients with PROP1 mutation received GH and sex hormone treatment since puberty and successful fertility was achieved later on (18). And finally, PROP1 mutation was identified in an elderly patient with osteoporosis due to previously unrecognized central hypogonadism and GH deficiency and hyperlipidemia due to central hypothyroidism (19). Thus, any comparison with current literature is difficult. However, several interesting points deserve discussion.

The first is the untypically delayed diagnosis due speculative reasons: possible difficult access to specialized healthcare in the Ukrainian countryside and surprising neglect of her continuing childish appearance by her family and by herself, which could not have been explained by psychic deterioration [described elsewhere (20) as a manifestation of PROP1 mutation]. Thus, such a case emphasizes the need for proper pediatric assessment, essential cooperation of the family and early referral of patients with growth retardation and delayed sexual maturation to a specialist.

Secondly, during the decision process about the indication of GH therapy in adulthood, several aspects had to be considered, such as justification of the treatment (physiological and economical) and the dose of $\mathrm{GH}$ [the initial pediatric dose $(12,21)$ had to be reduced to the adult dose very quickly due to adverse side effects]. Our recommendation for "growth hormone naive" cases is to start with lower than recommended doses. It is noteworthy that IGF-1 levels were not useful for monitoring the efficacy of GH treatment since during the follow-up they remained extremely low and their wide fluctuations (and corresponding changes of growth velocity) could have been associated with less than optimal compliance of the patient. Also, due to persistent enormous difference between bone and chronologic ages (possibly explained by delayed reaction of bone to hormonal treatment), the assessment of bone age was not very useful for guidance of GH treatment. Furthermore, psychological aspects were considered regarding the patient's reaction to sexual maturation.

The third point is connected with the initiation of hydrocortisone treatment despite normal initial cortisol levels and possible deleterious effects on growth and bone metabolism. Our decision was guided by decreased adrenal reserve in a challenge test, the trend to a decrease in basal cortisol in repetitive measurements and rapid up-titration of thyroxin, which could have increased the demands on the adrenocortical axis, and furthermore, such doses as ours were safe regarding bone metabolism (22) and growth (23). On the other hand, hydrocortison substitution does not seem to require dose adjustment after initiation of GH replacement (24).

Finally, the fourth point to be discussed is sex hormone substitution therapy. Our estradiol starting dose was not observed to effect growth, although a biphasic effect of estrogen on growth was described, with high concentrations leading to growth cessation, while low concentrations to its stimulation (25). On the other hand, "mini-estrogenization" had significant effects on previously hormone-naive, estrogen-dependent tissues (uterus, breast). In our patient, contrary to some observations (25), increased GH doses (due to HST) were not required. As typically seen in PROP1 mutation patients, our patient also failed to develop axillary and pubic hair (26). In addition, low values of dehydroepiandrosterone sulfate (DHEA-S) have been reported in the presence of a normal pituitary-adrenal axis in PROP1 mutation patients (27).

\section{CONCLUSION}

We present a case of an adult female patient with PROP1 mutation, which is unique particularly due to surprisingly late diagnosis of CPHD which included central hypogonadism with primary amenorrhea and growth retardation. Our case emphasizes the need for early diagnosis of CPHD based on proper pediatric assessment, good cooperation with the family, and early referral to an endocrinologist in patients with these symptoms. On the other hand, even an adult patient can profit from very cautiously combined GH therapy and sex hormone therapy, and can achieve normal height and regular menstrual cycle.

\section{ETHICS STATEMENT}

The case report was written with the recommendations of the Declaration of Helsinki. The patient is described anonymously 
and gave written informed consent with the publication. The presentation of the case report was approved by Ethics Committee of 3rd Faculty of Medicine, Charles University, Prague.

\section{AUTHOR CONTRIBUTIONS}

LB diagnosed the patient and wrote the manuscript. IC and $\mathrm{BK}$ led the growth hormone treatment and contributed to the preparation of the manuscript (GH treatment part and discussion part). JS and RP led the hormonal substitution treatment and contributed to the writing of the manuscript

\section{REFERENCES}

1. Wu W, Cogan JD, Pfäffle RW, Dasen JS, Frisch H, O’Connell SM, et al. Mutations in PROP1 cause familial combined pituitary hormone deficiency. Nat Genet (1998) 18:147-9. doi:10.1038/ng0298-147

2. De Rienzo F, Mellone S, Bellone S, Babu D, Fusco I, Prodam F, et al. Frequency of genetic defects in combined pituitary hormone deficiency: a systematic review and analysis of a multicentre Italian cohort. Clin Endocrinol (Oxf) (2015) 83(6):849-60. doi:10.1111/cen.12849

3. Madeira JLO, Nishi MY, Nakaguma M, Benedetti AF, Biscotto IP, Fernandes T, et al. Molecular analysis of Brazilian patients with combined pituitary hormone deficiency and orthotopic posterior pituitary lobe reveals eight different PROP1 alterations with three novel mutations. Clin Endocrinol (Oxf) (2017). doi:10.1111/cen.13430

4. Cheung LY, Davis SW, Brinkmeier ML, Camper SA, Pérez-Millán MI. Regulation of pituitary stem cells by epithelial to mesenchymal transition events and signaling pathways. Mol Cell Endocrinol (2017) 15(445):14-26. doi:10.1016/j.mce.2016.09.016

5. Lebl J, Vosáhlo J, Pfaeffle RW, Stobbe H, Cerná J, Novotná D, et al. Auxological and endocrine phenotype in a population-based cohort of patients with PROP1 gene defects. Eur J Endocrinol (2005) 153:389-96. doi:10.1530/eje.1.01989

6. de Graaff LCG. PROP1-related combined pituitary hormone deficiency. In: Pagon RA, Adam MP, Ardinger HH, et al., editors. GeneReviews ${ }^{\circledR}$ [Internet]. Seattle, WA: University of Washington, Seattle (2000). Available from: https://www.ncbi.nlm.nih.gov/books/NBK1347/

7. Bottner A, Keller E, Kratzsch J, Stobbe H, Weigel JF, Keller A, et al. PROP1 mutations cause progressive deterioration of anterior pituitary function including adrenal insufficiency: a longitudinal analysis. J Clin Endocrinol Metab (2004) 89:5256-65. doi:10.1210/jc.2004-0661

8. Birla S, Khadgawat R, Jyotsna VP, Jain V, Garg MK, Bhalla AS, et al. Identification of novel PROP1 and POU1F1 mutations in patients with combined pituitary hormone deficiency. Horm Metab Res (2016) 48(12):822-7. doi:10.1055/s-0042-117112

9. Flück C, Deladoey J, Rutishauser K, Eblé A, Marti U, Wu W, et al. Phenotypic variability in familial combined pituitary hormone deficiency caused by a PROP1 gene mutation resulting in the substitution of Arg $>$ Cys at codon 120 (R120C). JClin Endocrinol Metab (1998) 83:3727-34. doi:10.1210/jc.83.10.3727

10. Di Iorgi N, Morana G, Allegri AE, Napoli F, Gastaldi R, Calcagno A, et al. Classical and non-classical causes of GH deficiency in the paediatric age. Best Pract Res Clin Endocrinol Metab (2016) 30(6):705-36. doi:10.1016/j. beem.2016.11.008

11. Voutetakis A, Argyropoulou M, Sertedaki A, Livadas S, Xekouki P, Maniati-Christidi M, et al. Pituitary magnetic resonance imaging in 15 patients with PROP1 gene mutations: pituitary enlargement may originate from the intermediate lobe. JClin Endocrinol Metab (2004) 89:2200-6. doi:10.1210/ jc.2003-031765

12. Growth Hormone Research Society. Consensus guidelines for the diagnosis and treatment of growth hormone (GH) deficiency in childhood and adolescence: summary statement of the GH research society. J Clin Endocrinol Metab (2000) 85(11):3990-3. doi:10.1210/jc.85.11.3990
(HST part and discussion part). PS did all the auxology and contributed to the writing of the manuscript (auxology part and discussion part).

\section{ACKNOWLEDGMENTS}

A word of special thanks goes to Michael Allen for English editing.

\section{FUNDING}

This work was supported by Progres Q36.

13. Tanner JM, Goldstein H, Cameron N, Saunders WB, Healy MJR. Assessment of Skeletal Maturity and Prediction of Adult Height. 3rd ed. Philadelphia: WB Saunders (2001)

14. Tanner JM, Goldstein H, Whitehouse RH. Standards for children's height at age 2-9 years allowing for height of parents. Arch Dis Child (1970) 45:755-62. doi:10.1136/adc.45.244.755

15. Dušková J, Goldová $B$, Matiášková L, Beková $A$, Skřenková J. Contribution of hormonal cytology in girls and adolescents to reproductive health: a traditional technique monitoring recent problems. Acta Cytol (2017) 61(2):125-32. doi:10.1159/000470898

16. Hořejší J, et al. Dětská gynekologie. Mladá fronta (2017).

17. Jaramillo OV. First adult patient with a mutation in PROP1 treated with growth hormone in Costa Rica. Presented at Pituitary Hormone Deficiency: Diagnosis and Management. Endocrine Society's 96th Annual Meeting and Expo, June 21-24, 2014 - Chicago. (2014). SAT 0730. Available from: http:// press.endocrine.org/doi/abs/10.1210/endo-meetings.2014.NP.24.SAT-0730

18. Voutetakis A, Sertedaki A, Livadas S, Maniati-Christidi M, Mademtzis I, Bossis I, et al. Ovulation induction and successful pregnancy outcome in two patients with PROP1 gene mutations. Fertil Steril (2004) 82:454-7. doi:10.1016/j.fertnstert.2004.03.026

19. Andrikoula M, Sertedaki A, Andrikoula S, Dacou-Voutetakis C, Tsatsoulis A. PROP-1 gene mutations in a 63-year-old woman presenting with osteoporosis and hyperlipidaemia. Hormones (Athens) (2013) 12(1):128-34.

20. Chaudhary DP, Rijal T, Jha KK, Saluja H. PROP1 gene mutations in a 36-yearold female presenting with psychosis. Endocrinol Diabetes Metab Case Rep (2017). doi:10.1530/EDM-16-0096

21. Rohayem J, Drechsel H, Tittel B, Hahn G, Pfaeffle R, Huebner A. Longterm outcomes, genetics, and pituitary morphology in patients with isolated growth hormone deficiency and multiple pituitary hormone deficiencies: a single-centre experience of four decades of growth hormone replacement. Horm Res Paediatr (2016) 86(2):106-16. doi:10.1159/ 000448098

22. Wichers M, Springer W, Bidlingmaier F, Klingmüller D. How hydrocortisone substitution influences the quality of life and the bone metabolism of patients with secondary hypocortisolism. Eur J Clin Invest (2000) 30(Suppl 3):55-7. doi:10.1046/j.1365-2362.2000.0300s3055.x

23. Grigorescu-Sido A, Bettendorf M, Schulze E, Duncea I, Heinrich U. Growth analysis in patients with 21-hydroxylase deficiency influence of glucocorticoid dosage, age at diagnosis, phenotype and genotype on growth and height outcome. Horm Res (2003) 60(2):84-90.

24. Tschöp $\mathrm{M}$, Lahner $\mathrm{H}$, Feldmeier $\mathrm{H}$, Grasberger $\mathrm{H}$, Morrison $\mathrm{KM}$, Janssen OE, et al. Effects of growth hormone replacement therapy on levels of cortisol and cortisol-binding globulin in hypopituitary adults. Eur J Endocrinol (2000) 143(6):769-73. doi:10.1530/eje.0.1430769

25. Leung KC, Johannsson G, Leong GM, Ho KK. Estrogen regulation of growth hormone action. Endocr Rev (2004) 25(5):693-721. doi:10.1210/ er.2003-0035

26. Campbell B. Adrenarche and the evolution of human life history. Am J Hum Biol (2006) 18(5):569-89. doi:10.1002/ajhb.20528

27. Voutetakis A, Livadas S, Sertedaki A, Maniati-Christidi M, Dacou-Voutetakis C. Insufficient adrenarche in patients with combined pituitary hormone 
deficiency caused by a PROP-1 gene defect. J Pediatr Endocrinol Metab (2001) 14:1107-11. doi:10.1515/jpem-2001-0806

Conflict of Interest Statement: The authors declare that the research was conducted in the absence of any commercial or financial relationships that could be construed as a potential conflict of interest.
Copyright () 2017 Brunerova, Cermakova, Kalvachova, Skrenkova, Poncova and Sedlak. This is an open-access article distributed under the terms of the Creative Commons Attribution License (CC BY). The use, distribution or reproduction in other forums is permitted, provided the original author(s) or licensor are credited and that the original publication in this journal is cited, in accordance with accepted academic practice. No use, distribution or reproduction is permitted which does not comply with these terms. 